\title{
Nuclear Binding Sites in the Liver for Dexamethasone and in the Ventral Prostate for R1881
}

\author{
Sumiko ONOYAMA* AND SHOGo ICHII** \\ 1st Department of Internal Medicine* and Division of Physiology, \\ Institute of Steroid Research,** Tottori University School of Medicine, \\ Yonago, 683
}

\begin{abstract}
Nuclear binding sites which exhibit binding affinity similar to previously reported "Type II" sites (Clark et al., 1978) for estradiol in rat uterus were found in the liver and ventral prostate of rats and showed a binding specificity for glucocorticoid and androgen, respectively. However, both binding sites were qualitatively different from those of the rat uterus; a reducing agent, dithiothreitol, did not block the binding of steroids in the liver and ventral prostate. Extraction of the bound ligands discriminated the binding of the liver from that of the ventral prostate, Triton X-100 solubilized a majority of the bound Dex in liver nuclei, while the effect of $\mathrm{KCl}$ treatment was more remarkable on the bound $\mathrm{R} 1881$ in nuclei of the ventral prostate. Castration caused a drastic decrease in the binding of ventral prostate, only trace binding was observed at $48 \mathrm{~h}$ after hormone depriviation and replacement therapy restored the binding rapidly, at $3 \mathrm{~h}$ after testosterone injection almost $70 \%$ of the binding was detected. Although adrenalectomy did not result in a profound change in the binding sites of liver, the injection of Dex increased the number of binding sites significantly. The physiological significance of these binding sites is not clear at the present time.
\end{abstract}

It is widely accepted that most steroid hormones act by the same intracellular mechanism (Edelman, 1975, Gorski and Gannon, 1976, Mainwaring, 1975, O'Malley et al,. 1976).

\footnotetext{
Received February 9, 1982

** To whom reprint requests should be addressed.

The following trivial names are used; cortexolone; $17 \alpha, 21$-dihydroxypregna-4-ene-3, 20-dione, corticosterone; $11 \beta, 21$-dihydroxypregna-4-ene-3,20-dione, dexamethasone; $9 \alpha$-fluoro- $11 \beta, 17 \alpha, 21$-trihydroxy-16 $\alpha$-methyl-pregna-1, 4-diene-3, 20-dione, diethylstilbesterol ; (E)-4, 4'-(1,2-diethyl-1, 2-ethanediyl)-bisphenol, estradiol; 3,17 $\beta$-dihydroxy-estra-1,3,5-triene, dihydrotestosterone; $17 \beta$-hydroxy- $5 \alpha$-androstane-3-one, prednisolone; $11 \beta, 17 \alpha, 21$-trihydroxypregna-1, 4-diene-3, 20-dione, progesterone; pregna-4-ene-3,20-dione, R 1881; $17 \beta$-hydroxy- $17 \alpha$-methyl-4,9,11-estratriene-3-one, testosterone; $17 \beta$-hydroxy-4-androstene-3-one, triamcinolone acetonide; $9 \alpha$-fluoro- $11 \beta, 16 \alpha, 17 \alpha, 21$-tetrahydroxypregna-1,4-diene-2,20-dione cyclic 16,17 -acetal with acetone
}

In the scheme proposed for the general action mechanism of steroid hormones, the translocation of the hormone receptor complex to the nucleus after binding to a cytoplasmic receptor protein which is present only in target tissues is an obiligatory step. However, unoccupied nuclear receptors for estrogens were observed in nuclei from target cells (Jungblut et al., 1978, Levy et al., 1980) and breast cancer cells (Geier et al., 1979, Panko and MacLeod, 1978). Furthermore, Boesel et al. (1980) reported that the nuclear receptor content in the prostate of castrated rats increased after administration of testosterone without producing any reduction in total cytoplasmic androgen receptor content. From these observations, an alternative intracellular sequence for the action of steroid hormones which does not involve the "classical" translocation process 
has been suggested.

In previous reports, it was observed that depletion and subsequent replenishment of cytoplasmic receptors in rat liver after administration of various glucocorticoids were closely related to the dose as well as the biological potency of the hormones injected (Ichii, 1981) and, in the ventral prostate, the concentration of protein in the tissue increased during the period of receptor depletion and decreased along with the onset of the receptor replenishment (Ichii, 1980). On the other hand, Markaverich et al. (1981) reported that administration of dexamethasone (Dex) or progesterone blocked the stimulation of nuclear "Type II" binding sites for estrogens which were accompanied by inhibition of uterine growth without producing any changes in the pattern of dynamics of "classical receptors", depletion of the cytoplasmic and increase in nuclear receptors after administration of estrogens.

Although a number of studies have been carried out, the physiological significance of nuclear binding sites for steroids has not yet been fully elucidated. For this reason, close examination of nuclear binding of steroid hormones in target tissues seems to be worthwhile to throw light on the mechanism of steroid hormone action.

In the present study, nuclear binding sites for free ${ }^{3} \mathrm{H}$-Dex in the liver and for ${ }^{3} \mathrm{H}$-R 1881 in the ventral prostate of rats were examined.

\section{Materials and Methods}

\section{Animals and tissue preparations}

Male Wistar rats maintained under constant temperature $\left(24^{\circ} \mathrm{C}\right)$ and humidity $(60 \%)$ were used throughout the experiments. Livers were obtained from animals weighing 200-230 g which were adrenalectomized 10 14 days prior to sacrifice unless otherwise indicated. Ventral lobes of the prostate were removed from rats of $350-400 \mathrm{~g}$ body weight. In some experiments, rats castrated 24 or $48 \mathrm{~h}$ before sacrifice were used.

Tissues were homogenized in 5 volumes of ice-cold buffer solution which consisted of $50 \mathrm{~mm}$ Tris- $\mathrm{HCl}$ (pH 7.4), $25 \mathrm{~mm} \mathrm{KCl}, 5 \mathrm{~mm} \mathrm{MgCl}_{2}$ and $250 \mathrm{~mm}$ sucrose (TKMS buffer). The homogenate was centrifuged at
$600 \times g$ for $10 \mathrm{~min}$ to obtain crude nuclear fraction. Purification of the crude nuclear fraction was performed by the method of Blobel and Potter (1966) using $2.2 \mathrm{M}$ sucrose as a cushion. Purified nuclei were washed twice with TKMS buffer before use. Ventral prostates obtained from at least 3 rats were combined and processed simultaneously.

\section{Isotopes and other chemicals}

${ }^{3} \mathrm{H}$-labelled Dex (1,2(n)- $\left.{ }^{3} \mathrm{H}-, \quad 20 \mathrm{Ci} / \mathrm{mmole}\right)$ was obtained from the Radiochemical Centre (Amersham, U.K.) and ${ }^{3} \mathrm{H}-\left(17 \alpha\right.$-methyl- $\left.{ }^{3} \mathrm{H}-, \quad 87 \mathrm{Ci} / \mathrm{mmole}\right)$ and radioinert R1881 were purchased from New England Nuclear (Boston, USA). Other unlabelled steroids used were the products of Sigma Chemical Co. (Mo, USA). They were used without further purification.

\section{Determination of nuclear binding}

Nuclei (approx $150 \mu \mathrm{g}$ per tube as DNA) were suspended in $0.5 \mathrm{ml}$ TKMS buffer which contained a series concentration of ${ }^{3} \mathrm{H}$-labelled ligands (4 nM$500 \mathrm{~nm})$ and incubated at $0^{\circ} \mathrm{C}$ for $16 \mathrm{~h}$. After the incubation, $2.0 \mathrm{ml}$ of ice-cold TKMS buffer was added and the nuclei were recovered by centrifugation at $1,000 \times g$ for $5 \mathrm{~min}$. The precipitated nuclei were washed with $1 \mathrm{ml}$ of the ice-cold buffer twice and then bound ligand was extracted twice with $1 \mathrm{ml}$ of ethanol for determination of the radioactivity. Parallel incubations which included 500-fold molar excess of radioinert ligand were performed and the bound radioactivity which was not displaced by the addition of radioinert ligand was referred to as the nonspecific binding and subtracted in all instances. The specific binding (total binding - nonspecific binding) was analyzed by the method of Scatchard (1946). In some experiments, one point determination of the binding was carried out using a saturating amount of ${ }^{3} \mathrm{H}$ - ligand $\left({ }^{3} \mathrm{H}-\mathrm{Dex} ; 80 \mathrm{nM},{ }^{3} \mathrm{H}-\mathrm{R} 1881\right.$; $\left.65 \mathrm{~nm}\right)$. In experiments where effects of various steroids on the binding were examined, steroids were dissolved in ethanol, then diluted with TKMS buffer and added to the incubation medium. The final concentration of ethanol in the incubation medium never exceeded $0.2 \%$.

\section{Analytical methods}

DNA was determined by the method of Burton (1968). Radioactivity was measured in a Tri-Carb liquid scintillation spectrometer with automatic standardization for quenching correction.

\section{Results}

Saturation analysis of nuclear binding of free ${ }^{3} \mathrm{H}$-Dex and ${ }^{3} \mathrm{H}-\mathrm{R} 1881$ in the liver and ventral prostate

A saturable binding of nuclei isolated from 


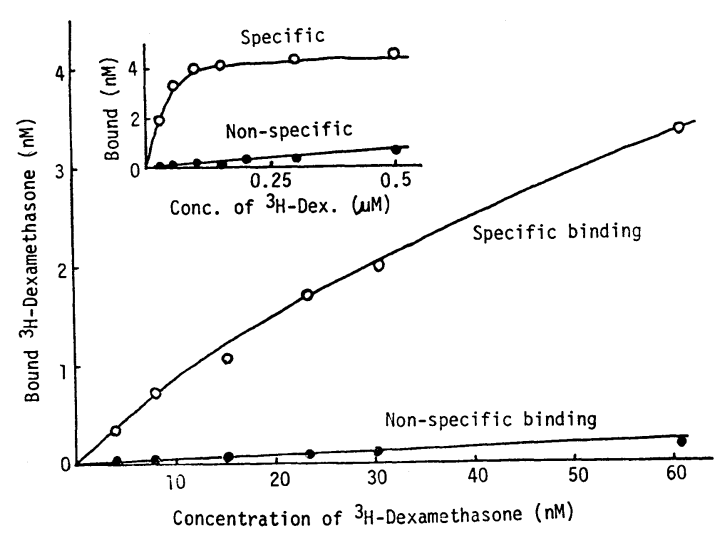

Fig. 1. Saturation analysis of ${ }^{3} \mathrm{H}$-dexamethasone binding in nuclei of the rat liver.

Purified nuclei were prepared from livers of adrenalectomized rats and duplicate aliquots $(132 \mu \mathrm{g}$ as DNA) were incubated in $0.5 \mathrm{ml}$ of TKMS buffer containing a series concentration of ${ }^{3} \mathrm{H}-\mathrm{Dex}(4 \mathrm{nM}-$ $500 \mathrm{nM}$ ) at $0^{\circ} \mathrm{C}$ for $16 \mathrm{~h}$. After incubation, nuclei were washed 3 times and bound radioactivity was determined as described in the section on Methods. In parallel incubations, a 500-fold molar excess of radioinert Dex was added and the radioactivity which was not displaced by the addition of radioinert Dex was subtracted to calculate the specific bindings. The insert shows the result of Dex binding using a broader range of the ligand.

livers of adrenalectomized rats to free ${ }^{3} \mathrm{H}$-Dex in TKMS buffer was observed (Fig. 1). Scatchard analysis revealed a single binding component which showed a dissociation constant $\left(\mathrm{K}_{\mathrm{d}}\right)$ of about $30 \mathrm{~nm}$ (Fig. 2).

In nuclei from the ventral prostate of intact rats, almost identical binding to that of liver nuclei to ${ }^{3} \mathrm{H}$-Dex to ${ }^{3} \mathrm{H}-\mathrm{R} 1881$ in TKMS buffer was observed (Fig. 3), but the rate of nonspecific binding was much higher than the binding of liver nuclei. $\mathrm{K}_{\mathrm{d}}$ of the binding was around $25 \mathrm{nM}$ (insert in Fig. 3).

\section{Steroid specificity of the binding}

The liver nuclei exhibited the binding specificity for glucocorticoids (Fig. 4). The binding was inhibited by the addition of radioinert Dex, corticosterone, prednisolone, cortexolone and progesterone but no significant effects of testosterone, estradiol, diethyl-

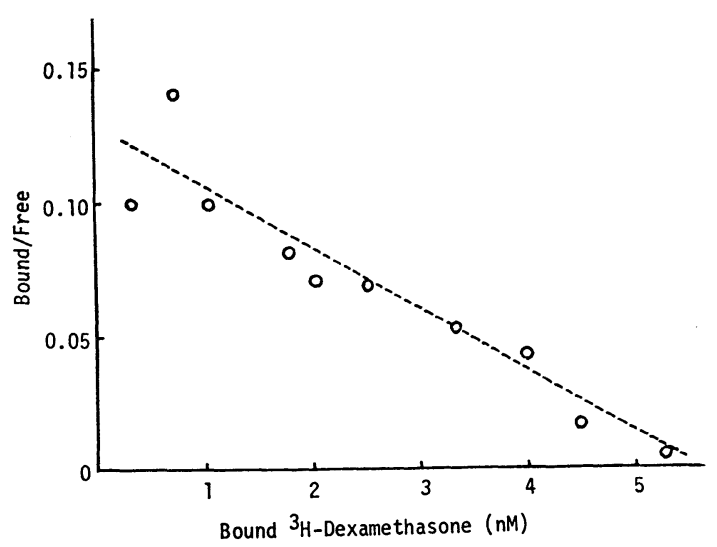

Fig. 2. Scatchard plot of the ${ }^{3} \mathrm{H}$-dexamethasone binding to liver nuclei. The quantity of ${ }^{3} \mathrm{H}-\mathrm{Dex}$ specifically bound to the liver nuclei (data of Fig. 1) was. plotted according to Scatchard (1949).

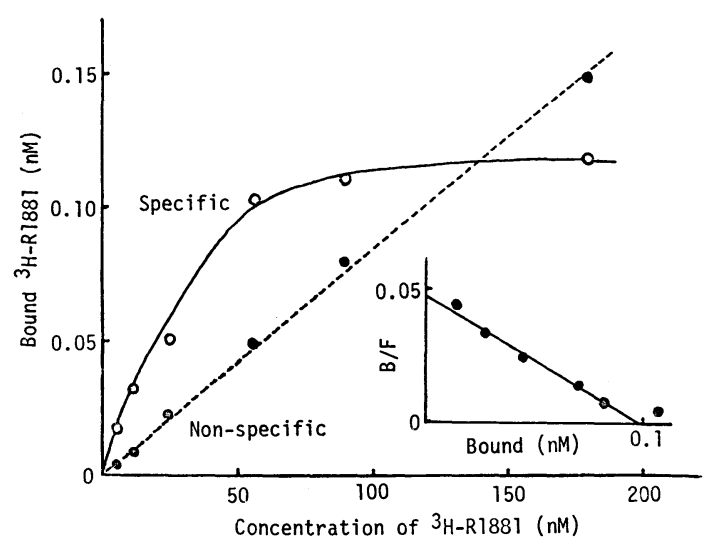

Fig. 3. Saturation analysis of ${ }^{3} \mathrm{H}-\mathrm{R} 1881$ binding in nuclei from the rat ventral prostate.

Duplicate samples of purified nuclei $(84 \mu \mathrm{g}$ as DNA) from the ventral prostate of intact rats were incubated in $0.5 \mathrm{ml}$ of TKMS buffer containing a series concentration of ${ }^{3} \mathrm{H}-\mathrm{R} 1881(4 \mathrm{nM}-180 \mathrm{nM})$ at $0^{\circ} \mathrm{C}$ for $16 \mathrm{~h}$ in the presence or absence of 500 -fold molar excess of radioinert R1881. Other conditions. were the same as described in the legend to Fig. 1. The insert shows the Scatchard analysis of the binding.

stilbesterol and triamcinolone acetonide were noticed even at high concentrations. No effect of triamcinolone acetonide on the binding was unexpected but it might be probable that the side chain of acetonide interfered with the binding. 


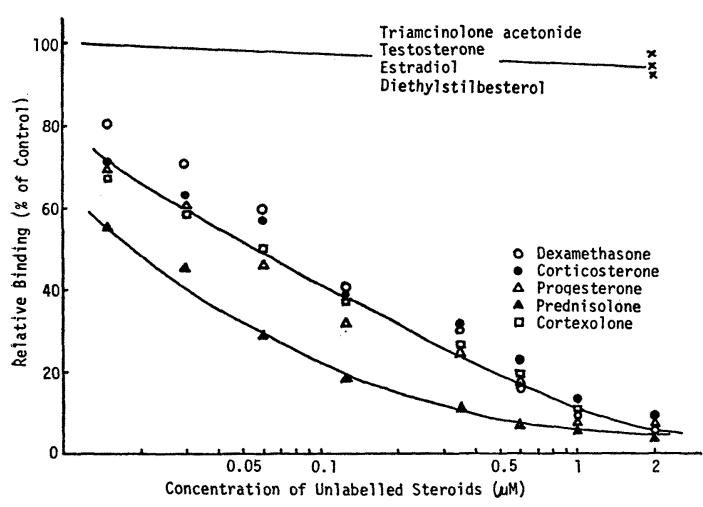

Fig. 4. Inhibition by various steroids of ${ }^{3} \mathrm{H}$-dexamethasone binding in liver nuclei.

Liver nuclei from adrenalectomized rats (152$218 \mu \mathrm{g}$ as DNA) were incubated with $50 \mathrm{nM}$ of ${ }^{3} \mathrm{H}$ Dex at $0^{\circ} \mathrm{C}$ for $16 \mathrm{~h}$. Competitors were dissolved in ethanol and diluted with TKMS buffer. The concentration of ethanol in the incubation mixture never exceeded $0.2 \%$. The nonspecific binding was subtracted in all instances as described in the section on Methods. The control bindings (no addition of competitor) varied from 13,600 to $19,900 \mathrm{dpm}$ depending on experiments and those were taken as 100 to calculate the relative bindings.

All three radioinert androgens examined competed against the ${ }^{3} \mathrm{H}-\mathrm{R} 1881$ binding in nuclei of the ventral prostate, while the rate of inhibition of the R1881 binding by other steroids was insignificant (Fig. 5).

\section{Exchange of the occupied binding sites}

To examine whether these nuclear binding sites were unoccupied or the result of the exchange of the occupied sites with ${ }^{3} \mathrm{H}$-ligands during the period of incubation, nuclei from the liver or the ventral prostate were preincubated in the presence of a saturating amount of radioinert Dex or $\mathrm{R} 1881$ at $0^{\circ} \mathrm{C}$ for $3 \mathrm{~h}$, and washed nuclei were further incubated with ${ }^{3} \mathrm{H}$-ligands at $0^{\circ} \mathrm{C}$ for $16 \mathrm{~h}$ in the presence or absence of a 500-fold molar excess of radioinert ligands. The results are summarized in Table 1 . In both cases, $60-70 \%$ of the occupied sites were exchanged with ${ }^{3} \mathrm{H}$ ligands in the incubation media even at $0^{\circ} \mathrm{C}$ during the incubation period. The non-

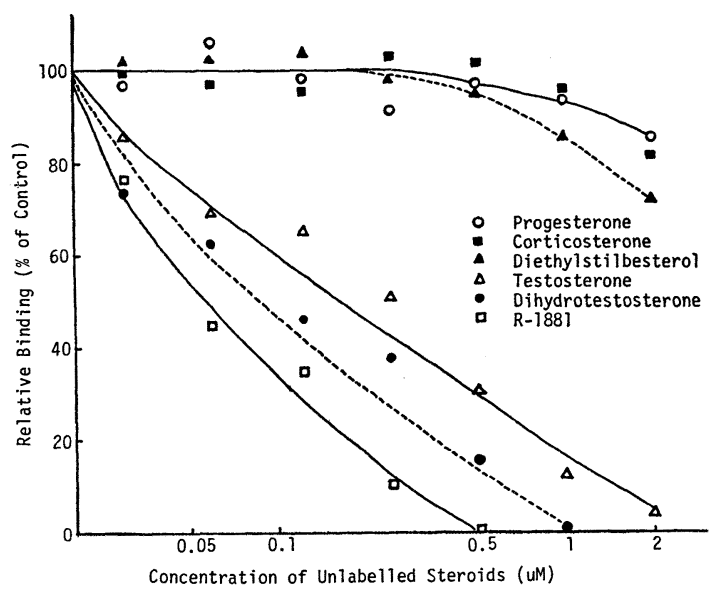

Fig. 5. Inhibition by various steroids of ${ }^{3} \mathrm{H}-\mathrm{R} 1881$ binding in nuclei from the ventral prostate.

Nuclei from the ventral prostate $(88-134 \mu \mathrm{g})$ obtained from intact rats were incubated with $35 \mathrm{nM}$ of ${ }^{3} \mathrm{H}-\mathrm{R} 1881$ in the presence or absence of radioinert competitors as described in the legend to Fig. 4. The nonspecific binding was subtracted in all instances. Control bindings (no addition of competitor) were $5190-6890 \mathrm{dpm}$ and those were taken as 100 to calculate the relative bindings.

specific binding seemed to be more readily exchanged; the preincubation did not reduce the nonspecific binding (data not shown). Along with the high rate of exchange in the nonspecific binding, dilution of the ${ }^{3} \mathrm{H}$ ligands in the incubation media with the dissociated radioinert ligands from the preincubated nuclei might take place during the incubation period, therefore the rates of exchange shown in the Table seem to be underestimated.

Extraction of the bound ligands with Triton $X$ 100 or $\mathrm{KCl}$ in TKMS buffer

Nuclei were incubated with a saturating amount of the respective ${ }^{3} \mathrm{H}$-ligand in the presence or absence of 500-fold molar excess of radioinert ligands and washed as the usual manner after incubations. The washed nuclei were suspended in $1 \mathrm{ml}$ of either $0.5 \%$ of Triton or $0.6 \mathrm{M} \mathrm{KCl}$ in TKMS buffer and shaken gently for $10 \mathrm{~min}$ (Triton) or $60 \mathrm{~min}$ 
Table 1. Exchange of nuclear bound radioinert ligands with ${ }^{3} \mathrm{H}$-labelled ligands during incubation at $0^{\circ} \mathrm{C}$.

\begin{tabular}{|c|c|c|c|c|c|}
\hline Nuclei & Exp. No. & 1st Incubation & 2nd Incubation & Bound & Rate of Exchange \\
\hline \multirow[t]{2}{*}{ Liver } & 1 & $\begin{array}{l}\text { None } \\
125 \mathrm{nM} \text { Dex }\end{array}$ & $\begin{array}{l}80 \mathrm{nM}^{3} \mathrm{H}-\mathrm{Dex} \\
80 \mathrm{nM}^{3} \mathrm{H}-D e x\end{array}$ & $\begin{array}{l}18500 \mathrm{dpm} \\
11970\end{array}$ & $65^{\%}$ \\
\hline & 2 & $\begin{array}{l}\text { None } \\
1 \mu \mathrm{M} \text { Dex }\end{array}$ & $\begin{array}{l}80 \mathrm{nM}^{3} \mathrm{H}-\text { Dex } \\
80 \mathrm{nM}^{3} \mathrm{H}-\text { Dex }\end{array}$ & $\begin{array}{l}20070 \\
11841\end{array}$ & 59 \\
\hline \multirow[t]{2}{*}{$\begin{array}{l}\text { Ventral } \\
\text { Prostate }\end{array}$} & 1 & $\begin{array}{l}\text { None } \\
100 \text { nM R1881 }\end{array}$ & $\begin{array}{l}65 \mathrm{nM}^{3} \mathrm{H}-\mathrm{R} 1881 \\
65 \mathrm{nM}^{3} \mathrm{H}-\mathrm{R} 1881\end{array}$ & $\begin{array}{l}6038 \mathrm{dpm} \\
4105\end{array}$ & $68^{\%}$ \\
\hline & 2 & $\begin{array}{l}\text { None } \\
1 \mu \mathrm{M} \text { R1881 }\end{array}$ & $\begin{array}{l}65 \mathrm{nM}^{3} \mathrm{H}-\mathrm{R} 1881 \\
65 \mathrm{nM}{ }^{3} \mathrm{H}-\mathrm{R} 1881\end{array}$ & $\begin{array}{r}13367 \\
8154\end{array}$ & 61 \\
\hline
\end{tabular}

In the first incubations, nuclei were suspended in $0.4 \mathrm{ml}$ of TKMS buffer in the presence or absence of an indicated amount of radioinert ligand at $0^{\circ} \mathrm{C}$ for $3 \mathrm{~h}$. After incubation, $2 \mathrm{ml}$ of ice-cold TKMS buffer was added and nuclei were recovered by centrifugation at $1,000 \times g$ for $5 \mathrm{~min}$. This washing procedure was repeated twice and washed nuclei were suspended in $0.4 \mathrm{ml}$ of TKMS buffer and subjected to the second incubation. Bound radioactivity was determined as described in the section on Methods. The following amounts (as DNA) of nuclei were used; Liver exp. 1, $210 \mu \mathrm{g}$, exp. 2, $240 \mu \mathrm{g}$, Ventral prostate exp. 1, 63 $\mu \mathrm{g}, \exp .2,124$ $\mu \mathrm{g}$ per tube.

Table 2. Extraction of nuclear bound ${ }^{3} \mathrm{H}$-ligands with Triton $\mathrm{X}-100$ and $\mathrm{KCl}$ in TKMS buffer

\begin{tabular}{|c|c|c|c|c|c|c|c|}
\hline \multirow{2}{*}{ Nuclei } & & \multicolumn{2}{|c|}{ Buffer } & \multicolumn{2}{|c|}{ Triton X-100 } & \multicolumn{2}{|c|}{$\mathrm{KCl}$} \\
\hline & & Residue & Extract & Residue & Extract & Residue & Extract \\
\hline \multirow[t]{3}{*}{$\begin{array}{l}{ }^{3} \mathrm{H}-\text { Dex bound } \\
\text { liver nuclei }\end{array}$} & $\begin{array}{l}\text { Total } \\
\text { binding }\end{array}$ & 6983 & - & 1930 & 3996 & 5041 & 814 \\
\hline & $\begin{array}{l}\text { Nonspecific } \\
\text { binding }\end{array}$ & 1230 & - & 4.63 & 379 & 555 & 196 \\
\hline & $\begin{array}{l}\text { Specific } \\
\text { binding }\end{array}$ & 5753 & - & 1453 & 3615 & 4485 & 618 \\
\hline \multirow{3}{*}{$\begin{array}{l}{ }^{3} \mathrm{H}-\mathrm{R} 1881 \\
\text { bound pro- } \\
\text { state nuclei }\end{array}$} & $\begin{array}{l}\text { Total } \\
\text { binding }\end{array}$ & 15581 & 293 & 5944 & 8144 & 7305 & 6409 \\
\hline & $\begin{array}{l}\text { Nonspecific } \\
\text { binding }\end{array}$ & 8632 & 216 & 1259 & 6985 & 5820 & 1716 \\
\hline & $\begin{array}{l}\text { Specific } \\
\text { binding }\end{array}$ & 6949 & 77 & 4.685 & 1159 & 1485 & 4693 \\
\hline
\end{tabular}

Nuclei from the liver of adrenalectomized rats (180 $\mu \mathrm{g}$ as DNA) and from the ventral prostate of intact control rats (402 $\mu \mathrm{g}$ as DNA) were incubated in the presence of $80 \mathrm{nM}$ of ${ }^{3} \mathrm{H}$-Dex or $65 \mathrm{nM}$ of ${ }^{3} \mathrm{H}-\mathrm{R} 1881$ at $0^{\circ} \mathrm{C}$ for $16 \mathrm{~h}$. After incubation, nuclei were washed 3 times with TKMS buffer and then divided into 3 equal parts. The divided nuclei were suspended either in TKMS buffer $(30 \mathrm{~min}), 0.5 \%$ Triton X-100 in TKMS buffer $(10 \mathrm{~min})$ or $0.6 \mathrm{M} \mathrm{KCl}$ in TKMS buffer $(60 \mathrm{~min})$ and left at $0^{\circ} \mathrm{C}$ for indicated time intervals with occasional shakings. After these treatment, each nuclear suspension was separated into residues and extracts by centrifugation at $6,000 \times \mathrm{g}$ for $10 \mathrm{~min}$. Radioactivity in aliquots of the extracts and ethanol extracts of the residues were measured. Figures in the Table are expressed as dpm. Another similar experiment was performed and essentially the same results were obtained.

$(\mathrm{KCl})$ at $0^{\circ} \mathrm{C}$. After the treatment, nuclear samples were centrifuged at $6,000 \times g$ for 10 min and the radioactivity in the pellets and supernatants was measured separately (Table 2). Treatment of liver nuclei prelabelled with ${ }^{3} \mathrm{H}$-Dex in vitro with the buffer which contained
Triton solubilized more than $60 \%$ of the ${ }^{3} \mathrm{H}-$ Dex bound specifically but only a small amount of the radioactivity appeared in the extract after treatment with the buffer containing $\mathrm{KCl}$.

In nuclei of the ventral prostate labelled 
Table 3. Effect of adrenalectomy, castration and hormone administration on the nuclear binding of liver and ventral prostate

\begin{tabular}{|c|c|c|}
\hline Nuclei from & No. of Exp. & Binding (pmoles/mg DNA) \\
\hline \multicolumn{3}{|l|}{ Liver of } \\
\hline Intact Control & 1 & $14.14 \pm 3.67$ \\
\hline Adrex & 19 & $9.24 \pm 0.90$ \\
\hline \multicolumn{3}{|l|}{ Adrex treated } \\
\hline with Dex $(3 \mathrm{~h})$ & 5 & $10.67 \pm 2.29$ \\
\hline$" \quad(24 \mathrm{~h})$ & 6 & $20.77 \pm 4.40$ \\
\hline \multicolumn{3}{|l|}{ Ventral Prostate of } \\
\hline Intact Control & 10 & $0.616 \pm 0.025$ \\
\hline Castrated $(24 \mathrm{~h})$ & 4 & $0.144 \pm 0.020$ \\
\hline$" \quad(48 \mathrm{~h})$ & 4 & $0.043 \pm 0.006$ \\
\hline \multicolumn{3}{|l|}{ Castrated $(48 \mathrm{~h}$ treated with } \\
\hline Testosterone $(3 \mathrm{~h})$ & 6 & $0.430 \pm 0.039$ \\
\hline " +Cyclohex & 2 & $0.482 \pm 0.072$ \\
\hline Testosterone $(24 \mathrm{~h})$ & 6 & $0.665 \pm 0.034$ \\
\hline
\end{tabular}

Duplicate samples of nuclei from the liver (approx $150 \mu \mathrm{g}$ as DNA) and ventral prostate (approx $120 \mu \mathrm{g}$ as DNA) were suspended in $0.4 \mathrm{ml}$ TKMS buffer which contained a saturating amount of ${ }^{3} \mathrm{H}-$ ligands $(80 \mathrm{nM}$; Dex, $65 \mathrm{nM}$; R1881) and incubated at $0^{\circ} \mathrm{C}$ for $16 \mathrm{~h}$. The bound radioactivity was determined as described in the section on Methods. In parallel incubations, 500-fold molar excess of radioinert ligands was included and the radioactivity which was not displaced by the addition of the radioinert ligand was subtracted in all instances.

For hormone injection, Dex ( $200 \mu \mathrm{g} / 100 \mathrm{~g}$ body weight) was dissolved in $0.2 \mathrm{ml}$ of $30 \%$ ethanol-saline solution and testosterone propionate $(1 \mathrm{mg} / 100 \mathrm{~g}$ body weight) was in $0.3 \mathrm{ml}$ cotton-seed oil. Both hormones were injected subcutaneously. Cycloheximide $(2 \mathrm{mg} / 100 \mathrm{~g}$ body weight $)$ in saline was administered intraperitoneally at the time of hormone injection.

with ${ }^{3} \mathrm{H}-\mathrm{R} 1881$, the majority of the radioactivity bound nonspecifically was solubilized by Triton, but only $20 \%$ of the specific binding was detected in the extract. At the same time, the buffer containing $\mathrm{KCl}$ extracted a larger portion of the specifically bound radioactivity but the effect of $\mathrm{KCl}$ on the ${ }^{3} \mathrm{H}$-ligand bound nonspecifically was rather small.

These results indicate that the bindings of Dex to the liver and of R1881 to the ventral prostate nuclei are qualitatively different.

Effect of adrenalectomy or castration on the binding

A slightly lower binding was observed in the nuclei from adrenalectomized rats when compared to that of the intact control rats, but the difference was statistically insignificant (Table 3). Administration of Dex $(200 \mu \mathrm{g} /$ $100 \mathrm{~g}$ body weight) did not change the binding at $3 \mathrm{~h}$ but the binding was significantly increased at $24 \mathrm{~h}$ post-injection $(\mathrm{p}<0.01)$.
While castration of the animals evoked a rapid fall in the binding of the ventral prostate, the binding dropped to $20 \%$ of that of the intact control at $24 \mathrm{~h}$ after castration and became a trace within $48 \mathrm{~h}$ after castration (Table 3). However, recovery of the binding after administration of testosterone propionate ( $1 \mathrm{mg} / 100 \mathrm{~g}$ body weight) was remarkably rapid, at $3 \mathrm{~h}$ after injection, almost $80 \%$ binding was observed, and the binding was recovered to the control level at $24 \mathrm{~h}$ postinjection. Concomitant administration of cycloheximide at a dose which inhibits ${ }^{3} \mathrm{H}$ leucine incorporation into acid-precipitable fraction $(2 \mathrm{mg} / 100 \mathrm{~g}$ body weight) hardly influence the replenishment of the nuclear binding at all at $3 \mathrm{~h}$ after testosterone injection but, due to the general toxicity of cycloheximide, longer experiments were not able to be performed. In the experiment on hormone injected animals, it is quite probable that the binding observed was underestimated, since 
the rate of exchange of occupied sites with ${ }^{3} \mathrm{H}$ ligands was less than $70 \%$.

\section{Effect of dithiothreitol on the binding}

Since Markaverich et al. (1981) reported the inhibition of "Type II" nuclear binding sites in the rat uterus for ${ }^{3} \mathrm{H}$-estradiol by reducing agents, the effect of various concentrations of dithiothreitol $(0.05-10 \mathrm{mM})$ on the binding of ${ }^{3} \mathrm{H}$-Dex and ${ }^{3} \mathrm{H}-\mathrm{R} 1881$ in nuclei from the liver and ventral prostate was examined. At variance with the observation of Markaverich et al. (1981), no significant effect of this reducing agent was detected throughout the concentrations used in the present study on either binding site (data not shown).

\section{Nuclear binding sites in other tissues}

Nuclear binding sites for free ${ }^{3} \mathrm{H}$-Dex were searched for in tissues other than the liver. Nuclei were isolated from the thymus, spleen, lung and heart in which appreciable an amount of the cytoplasmic glucocorticoid receptor was observed (Ichii, 1981). However, none of them exhibited a significant specific binding to ${ }^{3} \mathrm{H}$ Dex. A nuclear binding site for free ${ }^{3} \mathrm{H}-$ R1881 was revealed in the seminal vesicle and epididymus but not in the liver, thymus, spleen, lung or heart. The numbers of specific binding sites were 0.929 and 1.994 pmoles/mg DNA (average of 2 estimations) in the epididymus and seminal vesicle, respectively.

\section{Discussion}

Nuclear "Type II" binding sites for estradiol which exhibited considerably lower affinity and a greater number of binding sites were reported by Eriksson et al. (1978) and Clark et al. (1978), and these authors claimed the importance of these binding sites in growth response of the rat uterus to estrogen administration (Markaverich et al., 1981). Nuclear binding sites for Dex and R1881 with similar binding affinities were also detected in nuclei of the liver and ventral prostate of rats in the present study, but the properties of the binding in the liver and ventral prostate are different from those of the rat uterus. In the work of Markaverich et al. (1981), the nuclear "Type II" sites in the rat uterus do not bind ${ }^{3} \mathrm{H}$ estradiol in the presence of a minute amount of dithiothreitol (0.1-1.0 mM), while in our study the addition of various concentrations of this reducing agent $(0.05-10 \mathrm{mM})$ evoked no effect either on the nuclear binding sites for ${ }^{3} \mathrm{H}$-Dex in the liver or on those of ${ }^{3} \mathrm{H}$ R1881 in the ventral prostate. Extraction of the bound ${ }^{3} \mathrm{H}$-Dex and ${ }^{3} \mathrm{H}-\mathrm{R} 1881$ with Triton and $\mathrm{KCl}$ discriminated the binding of liver from that of ventral prostate; the majority of the bound ${ }^{3} \mathrm{H}$-Dex was easily solubilized in $0.5 \%$ Triton $\mathrm{X}-100$ and most of the bound ${ }^{3} \mathrm{H}-\mathrm{R} 1881$ remained in the nuclei of the ventral prostate after the treatment, while a high concentration of $\mathrm{KCl}$ extracted a large portion of the bound ${ }^{3} \mathrm{H}-\mathrm{R} 1881$ but effect of the salt solution on the bound ${ }^{3} \mathrm{H}$-Dex was relatively weak. From these observations, it is likely that nuclear binding sites in the uterus, liver and ventral prostate for free ligands are qualitatively different from each other, although all exhibit similar binding parameters.

The nuclear binding sites in the ventral prostate were decreased after castration and rapidly replenished after testosterone administration (Table 3). Lefebvre and Novosad (1980) observed binding sites for androgens in the nuclear envelope fraction isolated from the ventral prostate of rats and these sites were also diminished after castration. Based on this observation, they suggested that the binding sites in the nuclear envelope are involved in translocation of steroid-receptor complexes either into or out of the nucleus. The replenishment of the binding sites of castrated rats took place in a relatively short period after the administration of testosterone and restoration observed at $3 \mathrm{~h}$ after hormone administration was not blocked by concomitant administration of cycloheximide (Table 3). These results may provide another line of evidence supporting the view of Lefebvre and 
Novosad (1980). However, whether the nuclear binding sites observed in the present study are occupied or unoccupied are not clear at the present time since a partial exchange of the bound radioinert steroids with ${ }^{3} \mathrm{H}$-ligands took place during the incubation period even at $0^{\circ} \mathrm{C}$ (Table 1$)$.

In nuclei of the liver, adrenalectomy did not cause extreme changes in the binding capacity. However, administration of Dex to adrenalectomized rats increased the binding significantly within $24 \mathrm{~h}$ after injection and this indicated that these binding sites were also under the influence of glucocorticoids in some way.

In summary, the nuclear binding sites for free Dex which exhibited similar binding parameters to those of the "Type II" binding sites of rat uterus were observed in the liver but not in other target tissues of glucocorticoids, while the sites for free R1881 were present in target tissues of androgen examined but not in non-target tissues. These sites exhibited binding specificity to glucocorticoids or androgens and influenced by depriviation and also by administration of hormones. However, the physiological significance of these sites is not clear at all at present. Attempts to elucidate the role of these sites in the hormonal action of glucocorticoids and androgens are under way at this laboratory.

\section{References}

Blobel, G. and V. R. Potter (1966). Nuclei from rat liver: Isolation method that combines purity and high yield. Science 154, 1662-1665.

Boesel, R. W., R. W. Klipper and S. A. Shain (1980). Androgen regulation of androgen receptor content and distribution in the ventral and dorsolateral prostate of aging AXC rats. Steroids 35, 157-177.

Burton, K. (1968). Determination of DNA concentration with diphenylamine. Meth. Enzymol. XII, Part B, 163-166.

Clark, J. H., J. W. Hardin, S. Upchurch and H. Eriksson (1978). Heterogeneity of estrogen binding sites in the cytosol of the rat uterus. J. Biol. Chem. 253,
7630-7634.

Edelman, I. S. (1975). Mechanism of action of steroid hormones. J. Steroid Biochem. 6, 147-159.

Eriksson, H., S. Upchurch, J. W. Hardin, E. J. Peck and J. H. Clark (1978). Heterogeneity of estrogen receptors in the cytosol and nuclear fractions of the rat uterus. Biochem. Biophys. Res. Commun. 81, 1-7.

Geier, A., R. Ginzburg, M. Stauber and B. Lunenfeld (1979). Unoccupied binding sites for oestradiol in nuclei from human breast carcinoma tissues. $J$. Endocrinol. 80, 8185-8191.

Gorski, J. and F. Gannon (1976). Current models of steroid hormone action. Ann. Rev. Physiol. 38, $425-450$.

Ichii, S. (1980). Changes in the cytoplasmic androgen receptor of rat ventral prostate after administration of androgens, antiandrogens and anabolic steroids. Endocrinol. Japon. 27, 483-493.

Ichii, S. (1981). Depletion and replenishment of glucocorticoid receptor in cytosols of rat tissues after administration of various glucocorticoids. Endocrinol. Japon. 28, 293-304.

Jungblut, P. W., E. Kallweit, W. Sierrata, A. J. Truit and R. K. Wagner (1978). The occurrence of steroid-free "activated" estrogen receptor in target cell nuclei. Hoppe-Zeyler's Z. Physiol. Chem. 359, 1259-1268.

Lefebvre, Y. A. and Z. Novosad (1980). Binding of androgens to a nuclear-envelope fraction from the rat ventral prostate. Biochem. J. 186, 641-647.

Levy, C., R. Mortel, B. Eychenne, P. Robel and E. E. Baulieu (1980). Unoccupied nuclear oestradiol receptor sites in normal human endometrium. Biochem. J. 185, 733-738.

Mainwaring, W. I. P. (1975). Steroid hormone receptor: A survey. Vitam. Horm. 33, 223-245.

Markaverich, B. M. S. Upchurch and J. H. Clark (1981). Progesterone and dexamethasone antagonism of uterine growth: A role for a second nuclear binding site for estradiol in estrogen action. $J$. Steroid Biochem. 14, 125-132.

Markaverich, B. M., M. Williams, S. Upchurch and J. H. Clark (1981). Heterogeneity of nuclear estrogen-binding sites in the rat uterus: A simple method for the quantitation of Type I and Type II sites by ${ }^{3} \mathrm{H}$-estradiol exchange. Endocrinology 109, 62-69.

Panko, W. B. and R. W. MacLeod (1978). Uncharged nuclear receptor for estrogen in breast cancer. Cancer Res. 38, 1948-1951.

O'Malley, B. W., R. J. Schwarz and W. T. Schrader (1976). A review of regulation of gene expression by steroid hormone receptors. J. Steroid Biochem. 7, 1151-1159.

Scatchard, G. (1949). The attraction of protein for small molecules and ions. Ann. N.Y. Acad. Sci. 51, 660-672. 